\title{
INVESTIGATION OF VIRULENT AND TOXIN GENES EXPRESSION IN SOME SALMONELLA SEROVARS
}

\author{
A. Fekry ${ }^{(1)}$, S. Fahim ${ }^{(2)}$, Walaa Hussein ${ }^{(3)}$, Wafaa Hanafy ${ }^{(2)}$ \\ and A. Elbeltagy ${ }^{(2)}$ \\ ${ }^{(1)}$ Ministry of Health Central Laboratories, Cairo, Egypt. \\ (2) Agricultural Microbiology and Biotechnology, Botany Department, Faculty of \\ Agriculture, Menoufia University, Egypt. \\ (3) Genetics and Cytology Department, Genetic Engineering and Biotechnology Division, \\ National Research Centre (Affiliation ID : 60014618), Dokki, Egypt.
}

Received: Jan. 14,2020

Accepted: Feb. 15, 2020

\begin{abstract}
Samples collected from patient stool during their course of investigation at hospitals ministry of health, Egypt as well as solid and liquid food samples collected from local markets were examined for presence of Salmonella spp. Isolation and serological identification showed that $92.5 \%$ of collected samples contained Salmonella spp belonged to six serovars; Salmonella , enteritidis, Newport, derby, senftenberg and Virchow. These six serovars were checked by PCR for presence of three genes involved in virulence and toxin production, invA, avrA and stn. The gene invA was detected in all serovars, while avrA and stn genes were found in only 4 serovars. In this regard, S.typhimurium was found to harbour the three tested genes. When Salmonella typhimurium grew on normal synthetic medium and natural animal cells (Red blood; RBC and murine epithelial cells; IEC-6) and incubated separately at different temperatures 5, 25, 35 and $40 \mathrm{C}$ for $60 \mathrm{~h}$., they showed regular increase in growth rate with increasing temperature. Also, total RNA concentrations increased up to $24 \mathrm{~h}$. then slightly decreased at each examined temperature specially at 25, 35 and $40 \mathrm{C}$, but the highest RNA concentration was observed at $40 \mathrm{C}$. indicating its preparedness in the form of metabolic and cellular activities to cope with temperature stress. Moreover, $S$. typhimurium seems to be more potent and showed increased ability to induce the expression of enterotoxin gene (stn) by the exposure of temperature elevation specially when grown on murine epithelial cells; IEC-6 comparing with synthetic media or red blood cells.
\end{abstract}

Key words: Salmonella ; virulent genes; invA gene; avrA gene; enterotoxin gene (stn).

\section{INTRODUCTION}

Gastrointestinal diseases of infectious origin usually arise upon ingestion of contaminated foods or water and can have a wide number of etiological agents, known as enteric pathogens (Kabir et al., 2012). Among them, the genus Salmonella is of particular clinical relevance in both developed and developing countries, where this pathogen is one of the most common causes of food-borne illness and is a major cause of diarrheal diseases, respectively (Kozak et al., 2013). Salmonella enterica is one of the most common causes of foodborne infection in human beings and still the main cause of acute diarrhea syndrome, (McClelland et al., 2001). Salmonella enterica serovar Salmonella is a Gram negative, facultative Bacillus and a leading cause of human gastroenteritis, which is often associated with non typhoid symptoms such as diarrhoea and abdominal pain (Krtinc et al., 2010). In addition, result of usual occurrence of Salmonella organism in high concentration in wastewater and 
its long survival period in moist soil, more over cattle grazing on wastewater irrigated pasture could be infected with this microorganism. Furthermore, people could take the infection when drinking milk or eating meat from such infected cattle (Taylor et al., 1996). It has been reported that, about 46 countries including Egypt are using polluted water for irrigation purposes (UNHSP, 2008). However, the use of wastewater in irrigation involves many risks and negative impacts of great importance (Choukr-allah and Hamdy 2004). Among them the primary concern is to consumers using leafy green vegetables eaten uncooked and in raw salad dishes (Harris et al., 2003). Nevertheless, fresh leafy green vegetables and their ready to eat salads are recognized as a source of food poisoning outbreaks in many parts of the world (Mercanoglu et al., 2011). Detection methods must be able to detect both species and all serotypes, current methods for detecting Salmonella spp. require culturing, followed by a series of presumptive and confirmatory tests that take 5-7 days to complete, the widespread problems caused by Salmonella create the need for more rapid detection methods; however, the diversity of the organism has made it difficult to develop antibody-based or nucleic-acid-based methods that can detect every Salmonella serotype (FDA, 2015). Salmonella enterotoxin (Stn) is a putative virulence factor and causative agent of diarrhoea. It has been shown that the stn gene is specifically distributed only in Salmonella spp. irrespective of their serotypes ( Moore and feist 2007). Biological activities of Stn are important to Salmonella virulence, especially acute gastroenteritis. It has shown an enterotoxic activity in a murine ileal loop model. Therefore, Stn is a Salmonella virulence factor and is responsible for the enterotoxicity of Salmonella. It is possible that Stn will play a pivotal role in special functions of Salmonella (Chopra et al., 1999). Nucleic acid based techniques are being employed for the detection of various gene-encoded virulence factors invA and avrA genes that associated with Salmonella pathogenicity islands (SPIs) and stn gene involved in enterotoxin production. However, the distribution of these genes among various isolates obtained from biological sources is one of our aims This work allowed to know that in case of human infection the anti-biotherapy can be ineffective, and the Salmonella infection can be more severe. Identification of strains with high virulence potential and infectivity in the food at an early stage may help facilitate interventions reducing the risk of dissemination of epidemic strains.

\section{MATERIAL AND METHODES}

\section{Samples collection and preparation}

About 148 samples were collected from the Ministry of Health Laboratory and from the patients stool along their courses at Health Insurance Hospitals and others from local markets, Egypt. The patients' stool sampling were dole in sterile jars out the examined patients one day after sampling under the human stool collection instruction, each 5 grams of stool samples were mixed with $45 \mathrm{ml}$ of buffered peptone water (BPW) and well homogenized to form uniform slurry (Vadivelu et al., 1989). Liquid samples were collected approximately $50 \mathrm{ml}$ by using sterile plastic jar for soap, juice or potable water, each $5 \mathrm{gm}$ were mixed with $45 \mathrm{ml}$ of buffered peptone water (BPW) and well homogenized for bacteriological examination according to (APHA, 2015). For solid sampling, the homogenized 100 grams from the leafy greens or other solid food samples were taken by sterile gloved hand and directly transfer into sterile polyethylene bag, 
each $5 \mathrm{ml}$ were mixed with $45 \mathrm{ml}$ of buffered peptone water (BPW) and well homogenized using stomacher lab blender for bacteriological examination according to Benjamin et al., (1989).

\section{Isolation and detection of Salmonella}

The pre-enrichment step were applied for the prepared samples collected from different places, Salmonella resuscitation done by re-inoculated of Luria broth (LB) medium by $1 \mathrm{ml}$ of pre-enrichment culture media and incubated at $40^{\circ} \mathrm{C}$ for $12 \mathrm{~h}$. Then the cultures were streaked into modified Salmonella Shigella agar plates (Oxoid) and incubated at $40^{\circ} \mathrm{C}$ for $24 \mathrm{~h}$. After incubation, the black colonies on the plates were morphological examined and single colony was subcultured on xylose lysine deoxycholate XLD agar (Oxoid) at $40^{\circ} \mathrm{C}$ for $24 \mathrm{~h}$ as purification step according to Koneman et al., (1992).

\section{Serological examination of Salmonella serovars}

All purified Salmonella isolates were serologicaly examined at Immunity and Serology Unit, Ministry of Health laboratory. The polyvalent and monovalent antisera were used for serotyping detection by slide agglutination technique according to Kauffmann white Scheme (Kauffmann, 1974). The identified serovars used in the current study were routinely cultivated at $40^{\circ} \mathrm{C}$ in a Luria broth (LB) and stored at $20^{\circ} \mathrm{C}$ as seed cultures. Later, the exponential phase cells $\left(A_{600}=0.3\right)$ were grown in a minimal $E$ medium containing $0.4 \%$ glucose at $\mathrm{pH} 7.7$, which was then exposed to various examined temperatures according to Lee et al., (2001).

\section{Cultivation of Salmonella with animal cells}

The S. Salmonella serovar as described previously was grown to the exponential phase on LB medium and used to infect animal cells. RBCs or IEC- 6 cells $\left(2 \times 10^{5}\right)$ monolayer at a multiplicity of infection of about 1 to 10 as seeds to bacterial cells $\left(2 \times 10^{6}\right)$ and then incubated at the exposed temperatures during the period of investigation according to Liming and Bhagwat (2004).

\section{Growth and analytical determination}

Microbial growth determination, the cell density was measured by the cell dry weight (CDW) and measuring the density absorbance. A vacuum filtration (Buchner, Millipore $\AA 0.2 \mu \mathrm{m}, \mathrm{GR}$ ) were used for filtration, microbial filter disks were oven dried at $60^{\circ} \mathrm{C}$ for $24 \mathrm{~h}$. After drying it were cooled in a glass desiccator, the filters were weighed to calculate the difference between the weight after and before filtration which represents as CDW. The wave length of $600 \mathrm{~nm}$ (visible light) were used for optical density measurements, this wave length were found to have the least amount of the growth medium (Fahim et al., 2012).

\section{The total DNA and RNA determination}

The protocol of DNA Genomic purification kit was applied using the wizard of (Promega Co., Appl Microbiol Biotechnol Madison, USA). The total concentration of DNA was measured by $A_{260}$ direct method (1 ABS = $1 \mathrm{mg} \cdot \mathrm{mr}^{1}$ ), the absorption at $260 \mathrm{~nm}$ was measured using NanoDrop UV-Vis spectrophotometer (Thermo Fisher Scientific ${ }^{\mathrm{TM}}$ ). The purified DNA was directly used for PCR amplification or stored at $-20^{\circ} \mathrm{C}$. While, the total concentration of RNA was measured by $A_{230}$ direct method (1 ABS $=1 \mathrm{mg} \cdot \mathrm{mr}^{1}$ ), the absorption at $230 \mathrm{~nm}$ was measured using NanoDrop UV-Vis spectrophotometer (Thermo Fisher Scientific ${ }^{\mathrm{TM}}$ ). The purified RNA was directly used for PCR amplification or stored at $-20^{\circ} \mathrm{C}$ (Switzer et al., 1979). 


\section{A. Fekry, et al.,}

\begin{abstract}
For molecular weight determination, the sodium dodecyl sulphate polyacrylamide gel electrophoresis (SDSPAGE) profiles for extra-cellular degrading enzymes were preformed, the gel made of $(10 \%)$ polyacrylamide and $5 \%$ stacking gels. After electrophoresis run, the gels were stained with Coomassie brilliant Blue R-250 staining method and overnight de-stained by $45 \%$ methanol and $10 \%$ acetic acid (Pant et al., 2015). The gel was stained for $12 \mathrm{~h}$ in $0.1 \%$ coomassie brilliant blur and distained until bands were clearly observed. Gel bands were scanned and analysed using (Gel Doc Bio-Rad system, USA).
\end{abstract}

\section{Molecular detection and expression quantification techniques}

The Molecular detection of virulence potential genes involved in Salmonella serovars were investigated, the presence of three genes involved in virulence (invA, avrA and stn genes) were estimated in to six serovars of Salmonella typhimurium, enteritidis, newport, derby, senftenberg and Virchow from examined sources on account of their higher expansion.

\section{The isolation of Salmonella genomic DNAs}

DNA was isolated using Wizard $^{\circledR}$ Genomic DNA Purification Kit from Promega (USA), the isolation depends on four steps; step (1) is performed by nuclei lysis solution to lyses cells and nuclei; step (2) digestion of the RNA by RNase; step (3) is to precipitate and remove the cellular proteins by salt precipitation, which leaving only genomic DNA in solution; step (4) is to concentrate the genomic DNA by isopropanol precipitation and dissolution in a TE buffer. PCR technique was prepared by mixing $12.5 \mu \mathrm{l}$ of
RedTaq PCR Master Mix (Takara) from Japan with $1.5 \mu \mathrm{l}$ of each primer (20 pmol) and $50 \mathrm{ng}$ of DNA template, the reaction was completed to $25 \mu \mathrm{l}$ with (d. $\mathrm{H}_{2} \mathrm{O}$ ). The reaction was carried out in Eppendorff thermal cycler for 35 cycles under different temperature conditions depending on the investigated gene. PCR conditions and designed primers. All primers used in detection of virulence associated genes were listed and illustrated in (Table 1). Denaturation was performed for $5 \mathrm{~min}$ at $94^{\circ} \mathrm{C}$ for invA primers, for $10 \mathrm{~min}$ at $94^{\circ} \mathrm{C}$ for avrA and Stn primers. Hybridization at $55^{\circ} \mathrm{C}$ for 30 sec for invA, for $30 \mathrm{sec}$ at $58^{\circ} \mathrm{C}$ for avrA gene and for $45 \mathrm{sec}$ at $59^{\circ} \mathrm{C}$ for Stn gene. Elongation for $30 \mathrm{sec}$ at $72^{\circ} \mathrm{C}$ except for $35 \mathrm{sec}$ for Stn gene, a final extension was performed for 10 minutes at $72^{\circ} \mathrm{C}$ for all genes except for inva gene (for 7 minutes at $72^{\circ} \mathrm{C}$ ) according to (Hussein et al., 2016).

Agarose gel electrophoresis, $1.5 \%$ agarose gel was prepared to separate PCR products. Gels were colored by addition of Gel Red $10(\mu \mathrm{L} / 100 \mathrm{ml})$ and were run in an electrophoresis unit using $0.5 X$ TBE buffer $\mathrm{pH} 8.8$ at 100 volts for $\mathbf{1 . 5}$ $\mathrm{h}$, gels were photographed using gel documentation system.

Gel extraction after amplification, the extraction and purification of the different fragments were carried out by Gel extraction QIAquick kit from QIAGEN (Hildon, Germany), the QIAquick system is depend on spin-column technology with the properties of selective binding to silica-gel membrane. With each kit, special buffers are provided for DNA efficient recovery and contaminants removal, the silica-membrane bind DNA while contaminants pass through the column and are efficiently washed away, the purified DNA then is eluted with Tris buffer or water. 
investigation of virulent and toxin genes expression in some salmonella .....

\begin{tabular}{|c|c|c|c|}
\hline $\begin{array}{l}\text { Target } \\
\text { gene }\end{array}$ & Primer sequence ( $\left.5^{\circ}-3^{\prime}\right)$ & \multicolumn{2}{|c|}{$\begin{array}{l}\text { Product size }(b p) \\
\text { references }\end{array}$} \\
\hline \multirow{2}{*}{$\operatorname{invA}$} & GTGAAATTATCGCCACGTTCGGGCAA & \multirow[t]{2}{*}{284} & \multirow{2}{*}{$\begin{array}{l}\text { murugka } \\
\text { et al ( } 2003\end{array}$} \\
\hline & TCATCGCACCGTCAAAGGAACC & & \\
\hline \multirow{3}{*}{ avrA } & СCT GTA TTG TTG AGC GTC TGG & \multirow{3}{*}{422} & \multirow{3}{*}{ huehn } \\
\hline & AGA AGA GCT TCG TTG AAT GTC C & & \\
\hline & TTC TGC TCG CCG CTA TTC G & & \\
\hline \multirow{4}{*}{ Stn } & TTG TGT CGC TAT CAC TGG CAA CC & \multirow{4}{*}{617} & \multirow{4}{*}{$\begin{array}{r}\text { oliveira } \\
\text { et al ( 2003 }\end{array}$} \\
\hline & ATT CGT AAC CCG CTC TCG TCC & & \\
\hline & TTC CGG ATC CTT CAT TGA AAA ATC ССT CT & & \\
\hline & TAGGTAAAGTACTGCCGGAACTG & & \\
\hline
\end{tabular}

\section{Extraction of RNA}

The Ambion RNA-later kit (USA) was used for RNA extraction analysis. the storage of tissues can be indefinitely at $20^{\circ} \mathrm{C}$ or below, the cells are thawed on ice and then resuspended, the cells are centrifuged at $-9 \stackrel{\circ}{\circ}$ for $1 \mathrm{~min}$ at $12000 \mathrm{~g}$, after discard the supernatant and the pellet was resuspended in $50 \mu \mathrm{L}$ of $\mathrm{T} 10$ E1 buffer and $10 \mathrm{mg} / \mathrm{mL}$ lysozyme and incubated at room temperature for $\mathbf{1 0}$ min. The equivalent of $250 \mu \mathrm{L}$ of zirconium beads which were provided in the kit was added to the tubes, cells resuspended in $350 \mu \mathrm{L}$ of RNA wiz (provided in the kit) were transferred into tubes with beads. The RNA wiz contains phenol, which allows fragilization of the cells and inhibits the RNases, the whole was homogenized $10 \mathrm{~min}$ by vortex to lyse the cells, the samples were then centrifuged at $4^{\circ} \mathrm{C}$ for $5 \mathrm{~min}$ at $12000 \mathrm{~g}$. After that, a volume of $200 \mu \mathrm{L}$ was obtained and $200 \mu \mathrm{L}$ of chloroform were added, then the mix was agitated during $30 \mathrm{~s}$ and incubated at room temperature for $10 \mathrm{~min}$, samples were centrifuged at $4^{\circ} \mathrm{C}$ for $5 \mathrm{~min}$ at $12000 \mathrm{~g}$. The aqueous phase was obtained, $0.5 \mathrm{vol}$ of ethanol $100 \%$ was added and the whole sample was stirred vigorously, sample was loaded on the column provided by the kit to purify the RNA. The treatment by DNase was started and the RNA dosage measured by Spectrophotometer (WPA LIGHT WAVE II). 2.5 volume of ethanol 95\% was added to the RNA and stored at $-80^{\circ} \mathrm{C}$., Revert Aid First Strand cDNA Synthesis Kit (K1621, Fermentas) was used to the RNA reverse transcription into CDNA, PCR analysis was performed by reverse transcription products as templates (Hussein and fahim 2017).

The Real Time-PCR mixture of $25 \mu$ of total volume containing $1 \times$ SYBR green Fluorescein Mix, $1 \mu \mathrm{l}$ of cDNA and $250 \mathrm{nM}$ of each primer. The PCR program were performed at $95{ }^{\circ} \mathrm{C}$ for $5 \mathrm{~min}, 35$ cycles with $95^{\circ} \mathrm{C}$ for $20 \mathrm{~S}, 45 \mathrm{~S}$ at the annealing temperature depending on primer, $72^{\circ} \mathrm{C}$ for $40 \mathrm{~S}$ for 45 cycles. After amplification, a melt curve temperature was used to calculate the threshold cycles, results of RT-PCR were expressed as $C_{t}$ (cycle threshold) values and relative gene expression was quantified using stn gene primers as previously reported (Hussein and fahim 2017). 


\section{RESULTS AND DISCUSSION}

\section{Prevalence of recovered Salmonella}

One hundred and thirty seven Salmonella spp were isolated from 148 food and patients stools samples by percentage $92.5 \%$ of samples collected from the Ministry of Health Laboratory at Health Insurance Hospitals and local markets, Egypt. One hundred seventeen isolates were from one hundred stool samples, eighteen isolates were from forty eight food samples. The Salmonella isolates were serological identified to six serovars, Salmonella Typhimurium (109 isolates), Enteritidis (13 isolates), Newport (8 isolates), Derby (3 isolates), Senftenberg ( 2 isolates) and Virchow (2 isolate). However, the most Salmonella spp spreading in examined samples were the serovars of $S$. Typhimurium by percentage of $79.6 \%$ and eleven samples were found free from Salmonella by percentage of $8 \%$ according to these data were illustrated in Table (2).

The repeated isolates and serotypes diversity of Salmonella from samples in many investigation may reflect wide variance of pollution sources and could be assign to high probability human contact with animal stocking densities with subsequent the heavy uses of contaminated irrigated water. In addition, S. typhimurium, enteritidis and virchow serovars isolated from agricultural drains water in various studies which were found to be the most predominant among serovars of Salmonella from irrigated water such as Egypt, Southern Spain and Portugal (Dioniso et al., 2003). In Egypt, S. typhimurium and enteritidis serovars which isolated from cattle faeces were found the most common among all Salmonella serovars isolates from farm animals. While, the Salmonella isolated from cattle serovars are refer to the most dangerous role which could be played by cattle in salmonellosis dissemination to human and other animals (Moussa et al., 2013). Another investigation reported that, S. typhimurium serotype was the principle issue isolated from infected cattle and caused cereals contamination to by cattle farms when were used as grain stores, in addition that the cow's serovars, the target udder contamination with such microbes by pasture usually causes contamination of milk and others food-borne pathogens (Dwivedi and Jaykus 2011).

\section{DNA-based detection of virulence associated genes in Salmonella isolates.}

The molecular investigation of Salmonella serovars (typhimurium, enteritidis, newport, derby, senftenberg and Virchow) widely refer to that occurrence of invA, avrA and stn within the most virulence genes associated with Salmonella pathogenicity islands (SPIs), in the screened isolates with the ideal symptoms. The targeted virulence factors were examined in Don't ced by Salmonella isolates. The detection of invA gene by PCR was amplified a fragment of $284 \mathrm{bp}$ of length in all examined Salmonella isolates and a fragment of 422 bp of length for avrA gene was amplified from $S$. Typhimurium, Enteritidis, Newport, and Senftenberg isolates. While stn gene PCR amplified 617 bp fragment in $S$. typhimurium, enteritidis, newport, derby and virchow isolates. The presence of higher prevalence virulence associated three genes was detected in all isolated Salmonella genes conclude invA and avrA genes which associated with Salmonella pathogenicity islands (SPIs), while the stn is involved in enterotoxin production which illustrated in left side of Figure (1). 
investigation of virulent and toxin genes expression in some salmonella .....

Table (2): The prevalence of recovered Salmonella from different samples sources.

\begin{tabular}{|c|c|c|c|c|c|c|c|c|}
\hline \multicolumn{3}{|c|}{ Samples } & \multicolumn{6}{|c|}{ Salmonella serovars } \\
\hline Source & Type & $\mathbf{N}^{\circ}$ & Typhimurium & Enteritidis & Newport & Derby & Senftenberg & Virchow \\
\hline 1 & Stool & 57 & 56 & 7 & 4 & 0 & 0 & 2 \\
\hline 2 & Stool & 43 & 42 & 6 & 2 & 0 & 0 & 0 \\
\hline 2 & Food & 17 & 8 & 0 & 0 & 1 & 1 & 0 \\
\hline 3 & Food & 31 & 3 & 0 & 2 & 2 & 1 & 0 \\
\hline \multicolumn{2}{|c|}{ Total } & $148 / 137$ & 109 & 13 & 8 & 3 & 2 & 2 \\
\hline \multicolumn{2}{|c|}{ Percentage } & $92.5 \%$ & $79.6 \%$ & $9.5 \%$ & $5.8 \%$ & $2.1 \%$ & $1.5 \%$ & $1.5 \%$ \\
\hline
\end{tabular}

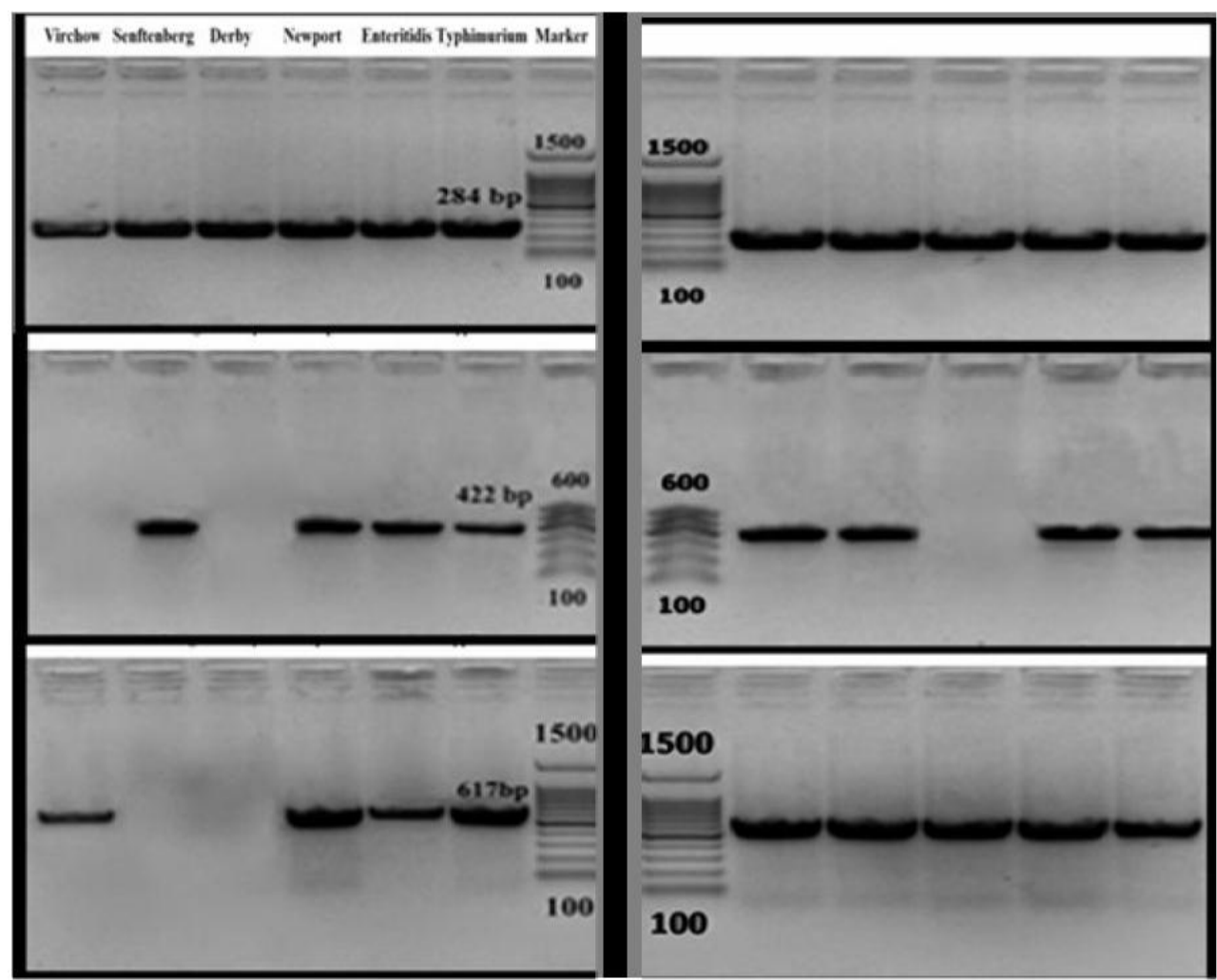

Fig (1): PCR amplification of invA, avrA and stn genes in examined Salmonella isolates (left) and $S$. Typhimurium serovar (right)

On other side, amplified invA, avrA and stn genes which involved in virulence associated factors with Salmonella (SPIs) were detected as overall values from most S. Salmonella isolates which illustrated in right side of Figure (1). Similar results, about the stn virulence gene was detected in all $S$. Salmonella isolated from different human sources, but it was detected in only 79 to $82 \%$ of $S$. Typhi and Paratyphi A, respectively (Muthu et al., 2014). The occurrence of invA gene in whole $S$. Salmonella isolates was agrees with 
those reported by (Osman et al. 2011) who found invA in whole serovars of $S$. Salmonella and enteritidis. While, avrA was found only in $51 \%$ of S. Salmonella and $48 \%$ of $S$. enteritidis isolates from various sources in Egypt. So, this investigation refer to widespread distribution of invA, avrA and stn virulence associated genes among the isolates which provided a strong evidence on virulent salmonellosis probability risks posed from various environmental sources. In addition, the diversity number of virulence markers distribution between screened Salmonella serotypes suggests that different topical species are likely to be responsible for different clinical syndromes in the host within those serovars. Also, to assess the virulence potential of isolated $S$. Salmonella serovars from the deferent sources, the presence of three amplified associated genes were detected in five of the most sever varying isolates of $S$. Salmonella serovars.

\section{RNA-based investigation of associated genes in Salmonella isolates.}

\subsection{RNA quantification and growth recovery}

The results of temperature elevation effect on S. Salmonella growth with time passing was determined for $0,12,24,36$, 48 and 60 hours, The quantification of total RNA concentration from $S$. Salmonella by regarding the individual temperature referred to increased in RNA from zero up to maximum concentration $(9.82 \mathrm{mg} / \mathrm{ul})$ at $40 \mathrm{c}$ during the first $24 \mathrm{~h}$ of bacterial growth, than gradually decreased, However, the growth at $5^{\circ} \mathrm{C}$ has shown RNA considerable stability in in total RNA concentrations up to 1.1 $\mu \mathrm{g} / \mu \mathrm{l}$. The integrity between the total RNA concentrations and growth rates were calculated to achieve the increasing levels of RNA activity by temperature elevation during $S$. typhimurium growth as illustrated on Figure (2).

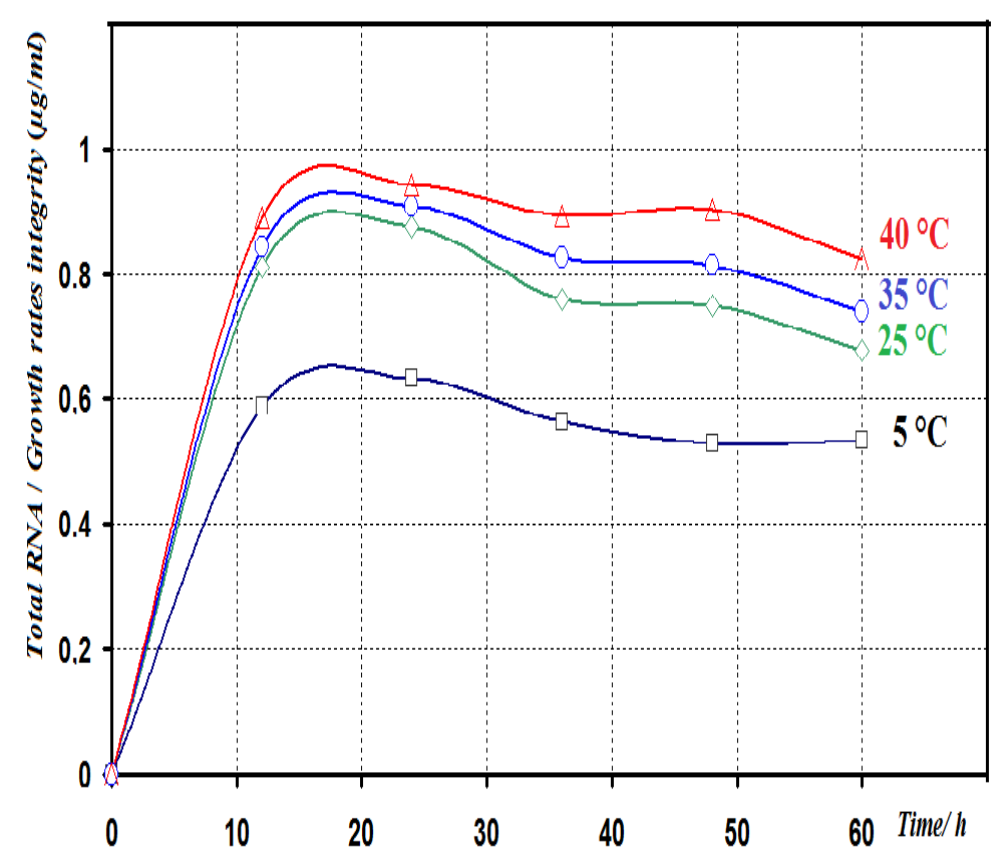

Figure (2): The recovery of temperature elevation effect on the integrity of $S$. typhimurium total RNA with its growth rates. 
In fact, the ribosomal-RNA forms 82$90 \%$ of total bacterial RNA and represented the active fraction between the cellular activity and bacterial metabolic state in environmental samples. The mRNA levels refers to genes expressions process and the rates of overall turnover activity so, many authors hypothesize that the total RNA determination could be qualitatively indication to the growing mode and active of microbial cells or it just present in idle state (Deutscher, 2006). similarly, our quantification investigation established that the integration between growth rates and the total RNA could be a qualitative coursers of the metabolic activity and then genes promoter activities by comparing the deference growth conditions to speculate genes activity. On other side, the quantity of total RNA were proportionally correlated with the temperature exposure during growth. Whereas, rising total RNA concentrations were detected from $S$. typhimurium which growing at room, optimum and elevated temperature, respectively when compared with growing at low temperature. Also, we found that total RNA were steadily rising during $24 \mathrm{~h}$ of Salmonella growth, even though, there was decline in optical densities after $36 \mathrm{~h}$ following of bacterial growth at optimum and elevated temperature, the activates averages were increased approximately by 6.66 and then $7.69 \%$ more than activates at room temperature, respectively. There was a positive correlation between the concentration of total RNA and $S$. Typhimurium growth in first 12 to hours which represented the exponential phase of bacterial growth curve, the continues increasing in total RNA concentration after $48 \mathrm{~h}$ at declined phase growth referred to Salmonella cellular activity prolonging and availability of protective environment, thus RNA content remained were more stable and extended active at ambient temperature. In addition that, reduction on cellular activity was observed at $5^{\circ} \mathrm{C}$ and complete metabolic disruption prevailed at $-20^{\circ} \mathrm{C}$, could be attributed due to the frozen conditions of cell contents as well as cell death, which can be attributed to cell death caused by frozen conditions of cell contents.(Data not shown)

\subsection{QRT-PCR validation and relative gene expression}

The gene expression of qRT-PCR amplification was quantified by analyzing the melting curve of $S$. typhimurium for stn genes which was a single peak, the analysed expression of reference gene (stn) was validated at various temperature exposures during exponential and stationary phases of the growth curve as shown in Figure (3).

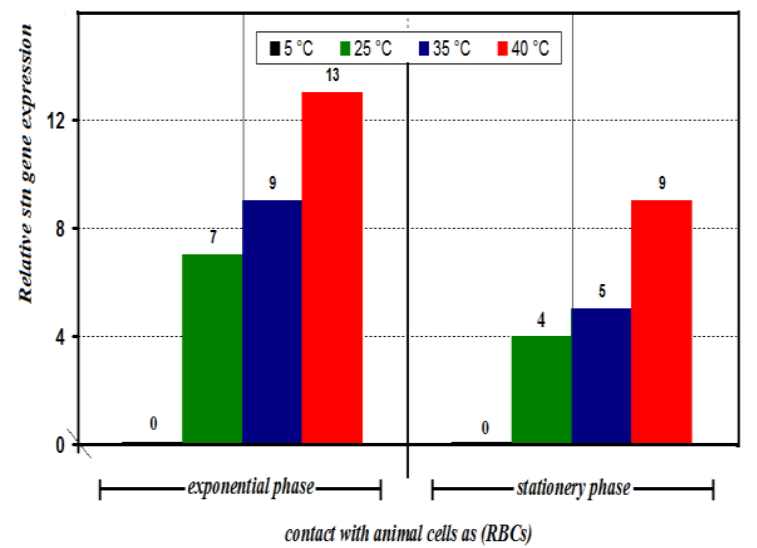

Figure (3): The effect of temperature on relative S. typhimurium stn gene expression. 
The stn target gene differential expression wasn't detectable in expression pattern and did not show any significance difference at $5^{\circ} \mathrm{C}$, this data confirmed that stn gene was consistent across the triggered by exposure to low temperature. Almost 4 fold up-regulation in stn target gene on the exponential phase, while an increasing by 2 fold was observed for it on stationary at room temperature. Also, considerable upregulation was observed by 5 and 9 fold on exponential phase throughout at 35 and $40^{\circ} \mathrm{C}$, respectively after that downregulation was observed by 3 and 7 -fold on stationary phase at 35 and $40^{\circ} \mathrm{C}$, respectively during exposure period. The total RNA concentrations resulted from various temperature exposure of $S$. Salmonella were used to investigate stn gene expression. the presented data the differences among the expressed stn gene at low, room and elevated temperatures; which were significantly down regulated at low temperature and substantially up-regulated at room temperature, nevertheless it was significantly up-regulated at elevated temperature. Also, the expression pattern of stn gene of S. Salmonella at various temperature remained up-regulated on 12 to $24 \mathrm{~h}$ of growth (exponential phase) and my be elongated more than $24 \mathrm{~h}$

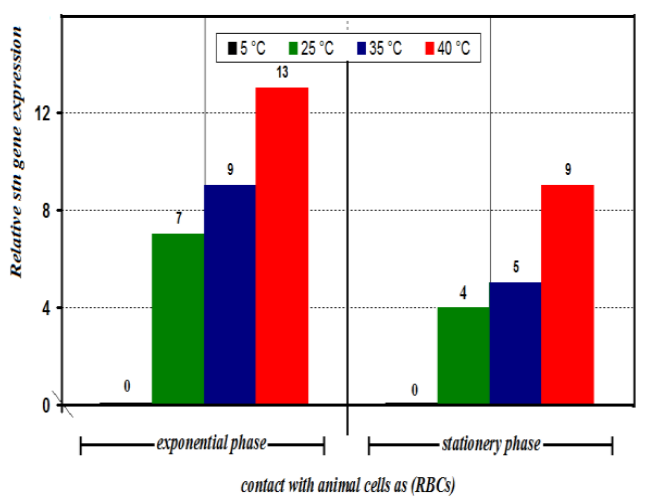

(stationery phase) thereafter down regulation was observed after $36 \mathrm{~h}$ (decline phase). The obtained results strongly referred to the induction of $S$. Salmonella stn target gene by exposture to the examined ambient temperature which could be contributing on pathogenicity vigour and virulent improvement, these results matched with those previously reported by (Lagha et al., 2012). However, the logically cause behind the static stn gene up-regulation could be returned to the high temperature induction by enhancing the promoter expression of stn gene in Salmonella (Bang et al., 2005).

\subsection{QRT-PCR in vivo validation and relative gene expression}

The in vivo gene expression of qRTPCR amplification was quantified by analyzing the melting curve of $S$. typhimurium for stn genes when growing in contact with animal cells, On other hand, the analysed expression of stn reference gene (stn) was validated with various temperature exposures during exponential and stationary phases of growth curve by additions of red blood cells (RBCs) or a murine epithelial cell line (IEC-6) as shown in Figure (4).

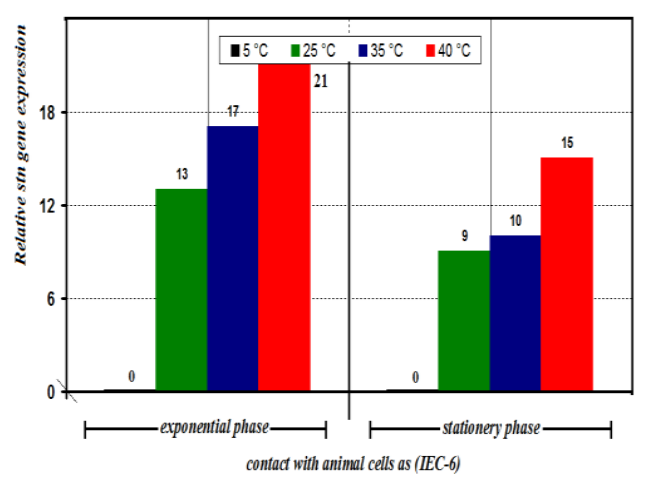

Figure (4): The effect of temperature on relative $S$. typhimurium stn gene expression by contact with animal cells as (RBCs) and (IEC-6) 
The differential expression of stn gene wasn't detectible within the pattern of target and did not show any significance difference at $5^{\circ} \mathrm{C}$, this data confirmed that stn gene was consistent across the triggered by exposure to low temperature. Seven fold up-regulation in stn genes during the exponential phase, whereas four fold up-regulation were obtained during stationary phase of the growth at room temperature. Considerable up-regulation was observed by 9 and 13-fold during exponential phase of growth throughout 35 and $40^{\circ} \mathrm{C}$, respectively after that downregulation was observed by 5 and 9 -fold on stationary phase of growth at 35 and $40^{\circ} \mathrm{C}$, respectively during exposure period. On other side, the differential expression of stn gene wasn't detectible within the pattern of target genes and did not show any significance difference at $5^{\circ} \mathrm{C}$, this repeated data confirmed that stn gene was consistent across the triggered by exposure to low temperature. Almost 13-fold up-regulation in stn genes during the exponential phase, whereas 9-fold increase was observed for them on stationary phase of growth at room temperature. Also, considerable upregulation were observed by 17 and 21fold during exponential phase throughout 35 and $40^{\circ} \mathrm{C}$, respectively after that downregulation was observed by 10 and 15fold on stationary phase at 35 and $40^{\circ} \mathrm{C}$, respectively during exposure period. The same expression pattern of stn gene of $S$. typhimurium was the same when contact with animal cells as (RBCs) or (IEC-6) at various temperature as remained upregulated on 12 to $24 \mathrm{~h}$ of growth (exponential phase) and my be elongated more than $24 \mathrm{~h}$ (stationery phase) thereafter down regulation was observed up to $36 \mathrm{~h}$ (decline phase) Figure (5).

The up-regulated expression values were significally increased when contact with (RBCs) and approximately duplicated when contact with (IEC-6) as indicator for the specificity of Salmonella with these type of animal cells which to be similar to the in nature vivo condition. In Earlier investigations concluded that, the method of mRNA isolation as technique for study transcriptional regulation was recently used to investigate whether the target stn genes are actually active in a native environment. However, all strains of Salmonella enterica carry the stn gene but little number of its serovars have been detected phenotypically to exaggerate the enteric toxin (Prager et al., 1995). Also, (Mekalanos, 1992) reported that, the stn gene was overexpressed after many years of starvation in seawater which in turn is able to contributing more vigour towards its virulent. While, the virulence genes expression might be based on appropriated environmental factors, but it absolutely inadequate under common laboratory cultivation in vitro conditions. However, it must be know that the specific virulence factors specification could be established inner the host under infection in vivo condition. Consequently, the Salmonella enumeration in contact with epithelial cells types of IEC- 6 cells due to an augmentation in the enterotoxin productivity. And also achieved that, the target stn gene promoter expression need to epithelial cells specific induction signal. 


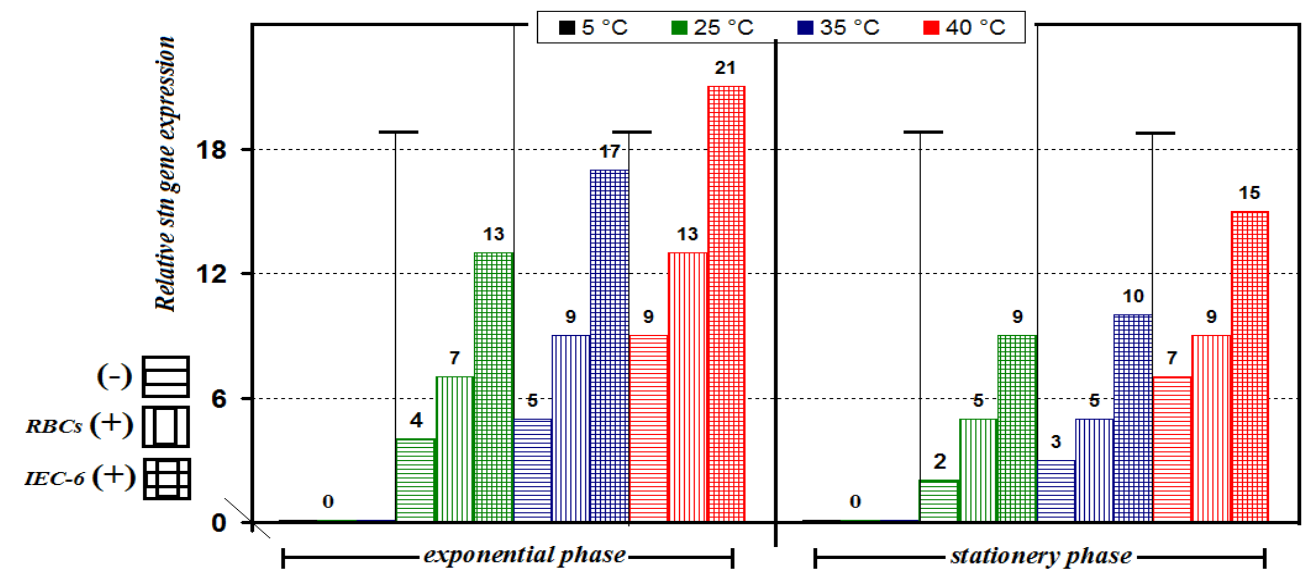

Figure (5): The effect of temperature on relative S. typhimurium stn gene expression with and without contact by various animal cells

\section{Acknowledgements}

This study was conducted by Agricultural Microbiology and Biotechnology Laboratory, Botany Department, Faculty of Agriculture, Menoufia University, Egypt.

\section{REFERENCES}

Apha (American Public Health Association): (2015). Standard Methods for examination of water and wastewater, 23rd ed. Washington DC, USA,

Bang, I.S., J.G. Frye, M. McClelland, J. Velayudhan and F.C. Fang (2005). Alternative sigma factor interactions in Salmonella: $\sigma^{\mathrm{E}}$ and $\sigma^{\mathrm{H}}$ promote antioxidant defences by enhancing $\sigma^{\mathrm{S}}$ levels. Mol Microbiol.; 56:811-23.

Benjamin, I., E. R. Atwill, M. Jay-Russell, M. Cooley, D. Carychao, L. Gorski and R. E. Mandrell (1989). Occurrence of generic Escherichia coli, E. coli 0157 and Salmonella spp. in water and sediment from leafy green produce farms and streams on the Central California coast. Int. J. Food Microbiol., 165, 65-76.

Chopra, A. K., J. H. Huang, X. J. Xu, K. Burden, D. W. Niesel, M. W. Rosenbaum, V. L. Popov and J. W.
Peterson (1999). Role of Salmonella enterotoxin in overall virulence of the organism. Microb. Pathog.,; 27: 155171.

Choukr-allah, R. and A. Hamdy (2004). Wastewater treatment and reuse in Mediterranean region as a potential resource for drought mitigation. In: Hamdy, A. (ed.) Water Management for Drought Mitigation in the Mediterranean (Proc. Workshop, 2nd Regional Conference on Arab Water, Cairo, April 12-16), Egypt National Water Resources Centre and CIHEAMIAMB, Bari, pp. 103-132.

Dionisio, LPC., M. V. Joao, S. Ferreiro, M. L. Fidalgo, M. E G. Rosado and J. J. Borrego (2003). Occurrence of Salmonella spp in estuarine and coastal waters of Portugal. Antonie van Leeuwenhoek,; 78, 99-106.

Dwivedi, H. P. and L.A. Jaykus (2011). Detection of pathogens in foods: the current state-of-theart and future directions. Critical Reviews in Microbiology, 37(1), 40-63.

Fahim, S., K. Dimitrov, F. Gancel, P. Vauchel, P. Jacques and I. Nikov (2012). Impact of energy supply and oxygen transfer on selective lipopeptide production by Bacillus 
subtilis BBG21. Biores technol; 126: 16.

Food and Drug Administration. (2015). Bacteriological Analytical Manual Online. Available at: http://www.cfsan.fda.gov/_ebam/bamtoc.html.

Harris, I. J., J. M. Farber, L. R. Beuchat, M. E. Barish, T.V. Suslow, E. H. Garrett and F. Busta (2003). Outbreaks associated with fresh produce: incidence, growth, and survival of pathogens in fresh and fresh-cut produce. Comprehensive Rev. Food Sci. Food Safety, 2,; 78-141.

Hussein, W., H. Awad and S. Fahim (2016). Systemic Resistance Induction of Tomato Plants Against ToMV Virus by Surfactin Produced from Bacillus subtilis BMG02. Americ $\mathrm{J}$ Microbiol Res, 4 5: 153-158.

Hussein, W. and S. Fahem (2017). Detection of synthetases genes involved in non ribosomal lipopeptiedes (NRLPS) biosynthesis from Bacillus species by bioinformatics and PCR degenerated primers and estimation of their production . Int . J . pharma . Bio .Sci . $82: 116$.

Huehn, S., R. M. La Ragione, M. Anjum, M. Saunders, M. J. Woodward, C. Bunge, R. Helmuth, E. Hauser, B. Guerra, J. Beuttich, A. Brisabois, T. Peters, L. Svensson, G. Madajczak, E. Litrup, A. Imre, Herrera-Leon., D. Mevius, D. G. Newell and B. Malorny (2009). Virulotyping and antimicrobial resistance typing of Salmonella enterica serovars relevant to human health in Europe. Foodborne pathog. Dis., 7, 523-535.

Kabir, M.R., M.A. Hossain, S.K. Paul, C. Mahmud, S. Ahmad, N.U. Mahmud, S. Sultana, T. Yesmin, S.M. Hoque, U. Habiba, M.A. Rahman and Kobayashi (2012). Enteropathogens associated with acute diarrhea in a tertiary hospital of Bangladesh. Mymen singh. Med. J., 21:618-623.

Kauffman, G. (1974). Kauffmann-white scheme.WHO-BD, Rev., 1. Acta Path. Microbiol. Scand., 61, 385-394.

Koneman, E.W., S.D. Allen, E.M. Janda, C. Schrekenberger and W.C. Winn (1992). Diagnostic Microbiology. J.B. Lippincott Company, USA,.

Kozak, G.K., D. Macdonald, L. Landry and J.M. Farber (2013). Foodborne outbreaks in Canada linked to produce: 2001 through 2009. J. Food Prot., 76:173-183.

Krtinc, G., P. Durić and S. Llić (2010). Salmonella in food stuffs of plant origin and their implications on human health. Eur. J. Clin. Microbiol. Infect. Dis., 29,; 1321-1325.

Lee, Y., H. Kwon, S.H. Lee, H. Kwon, H.C. Sung, J. Kim and M. Choe (2001). Identification of a gene for aerobic growth with a SoxS binding sequence in Escherichia coli by operon fusion techniques. J. Microbiol. Biotechnol. 11:1115-1119.

Liming, S.H. and A.A. Bhagwat (2004). Application of a molecular beacon real-time PCR technology to detect Salmonella species contaminating fruits and vegetables. Int,J, Food Microbial ,95;177-187.

McClelland, M., K.E. Sanderson, J. Spieth, S.W. Clifton, P. Latreille and L. Courtney (2001). Complete genome sequence of Salmonella enterica serovar Typhimurium LT2. Nature; 413:852- 856.

Mekalanos, J.J. (1992). Environmental signals controlling expression of virulence determinants in bacteria. $\mathrm{J}$. Bacteriol. 174, 1-7.

Mercanoglu, T. B. and A. K. Halkman (2011). Do leafy green vegetables and their ready-to-eat [RTE] salads carry a risk of foodborne pathogens? Anaerobe, , 17; 286-287. 
Moore, M. M. and M. D. Feist (2007). Realtime PCR method for Salmonella spp. targeting the stn gene. J. Appl. Microbiol.; 102: 516-530.

Moussa, I. M., Y. S. Aleslamboly, A. A. Al-arfaj, A. M. Hessain, A. S. Gouda and R. M. Kamal (2013). Molecular characterization of Salmonella virulence genes isolated from different sources relevant to human health. $J$. Food Agri. Environ., 11: 197-201

Murugkar, H. V., H. Rahman and P. K. Dutta (2003). Distribution of virulence genes in Salmonella serovars isolated from man and animals. Indian J. Med. Res., , 117, 66-70.

Muthu, G., A. Suresh, D. Vishnuprabu, A. K. Munirajan, S. Esther Mary, E. Sathishkumar, P. Gopinath and S. Srivani (2014). Detection of virulence genes from Salmonella species in Chennai, India. CIB Tech J. Microbiol., 3, 11-14

Olvera, S. D., C. R. Rodenbusch, M.C. CE, S. L. S. Rocha and C. W. Canal (2003). Evaluation of selective and nonselective enrichment PCR procedures for Salmonella detection. Lett. Appl. Microbiol., 36, 217-221.

Osman, G. A., H. M. Hassan and M. M. Kamel (2011). Resistance and sensitivity of some bacterial strains isolated from hospital wastewater and Nile water using chlorination and some antibiotics in Cairo (Egypt). $J$. Am. Sci., , 7: 1033-1041.

Pant, G., A. Prakash, JVP Pavani, S. Bera, GVNS Deviram, A. Kumar, $\mathbf{M}$. Panchpuri and RG Prasuna (2015).
Production, optimization and partial purification of protease from Bacillus subtilis, J. Taibah Univ. Sci., 9: 50-55.

Prager, R., A. Fruth and H. Tschape (1995). Salmonella enterotoxin (stn) gene is prevalent among strains of Salmonella enterica but not among Salmonella bongori and other Enterobacteriaceae. FEMS Immunol. Med. Microbiol., 12,: 47-50.

Switzer, R.C., C.R. Merril and S. Shifrin (1979). A highly sensitive silver stain for detecting proteins and peptides in polyacrylamide gels. Analytical Biochemistry, 98: 231-237.

Taylor, C., J. Yahner, D. Jones and A. Dun (1996). Waste and Public Health. On-site Wastewater Disposal and Public Health. Purdue on-site Wastewater Disposal. Purdue Wastewater Articles on-line, Purdue University. Pipeline Summ. 7:3 .

Unhsp (United Nations Human Settlements Programme): (2008). in R. LeBlanc, P. Matthews and P. Roland (eds) Global Atlas of Excreta, Wastewater Sludge, and Biosolids Management: Moving Forward the Sustainable and Welcome Uses of a Global Resource, UN-Habitat, Nairobi, p632,

Vadivelu, J., R. G. Feachem, B. S. Drasar, T. J. Harrison, N. Parasakthi, V. Thambypillai and S. D. Puthucheary (1989). Enterotoxigenic Escherichia coli in the domestic environment of a Malaysian village. Epidemiol. Infect., 103,; 497-511. 
دراسات على منظمات التعبير الجينى لبعض بكتيريا التسمم الغذائى (السالمونيلا)

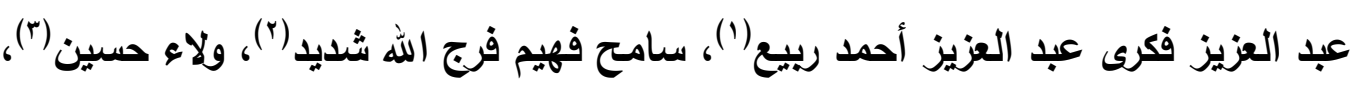

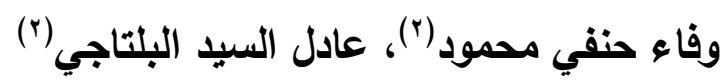

$$
\text { (1) (1) المعامل المركزية بوزارة الصدة - القاهرة }
$$

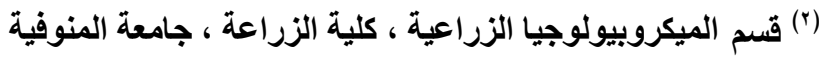

(") (بالمركز القومى للبحوث

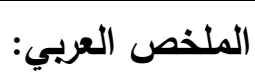

فصص التعبير الجينى لجينات الضراوة والتسم فى بعض الانواع السيرولوجيه للسالمونيلا

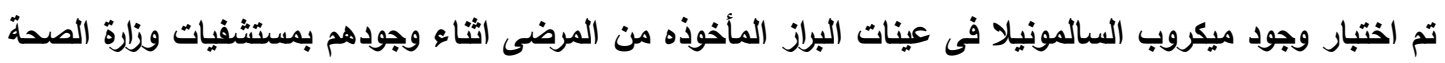

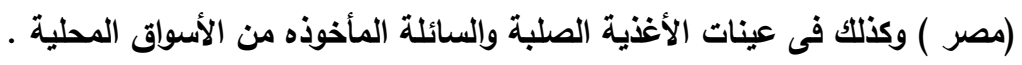

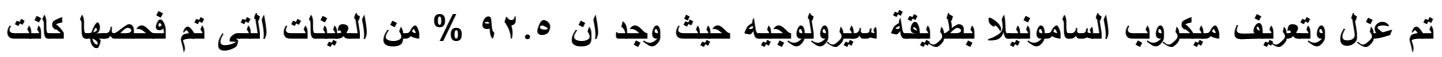

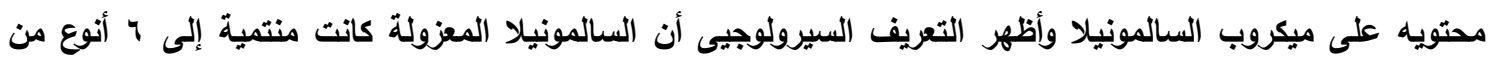
جنس السالمونيلا وهم :

$$
\text { Salmonella - Enteritidis - Newport - Derby - Senftenberg - Virchow }
$$

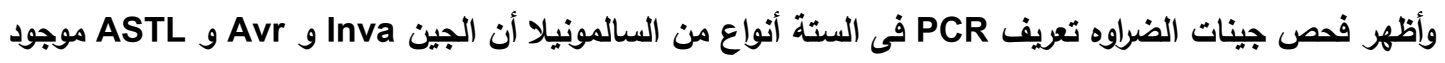

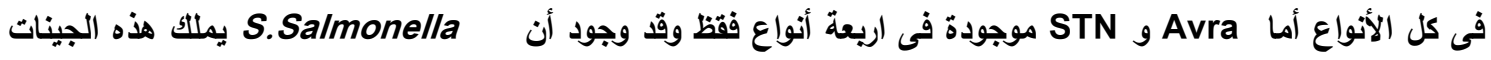

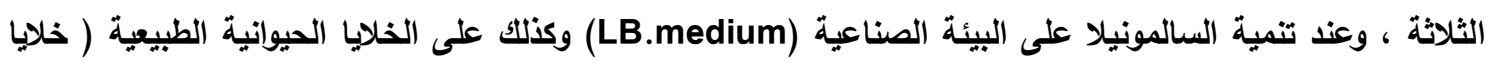

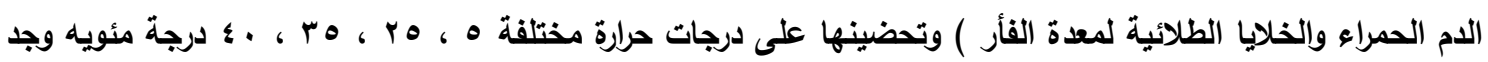

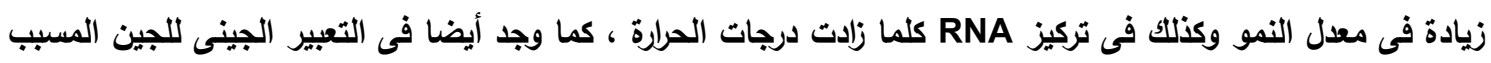

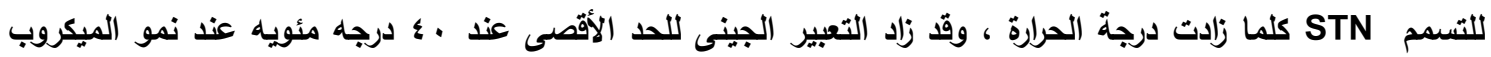

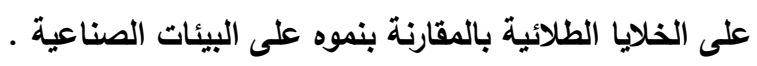

أ.د/ خميس كامل كعبارى كلية الززاعة - جامعة المنوفية

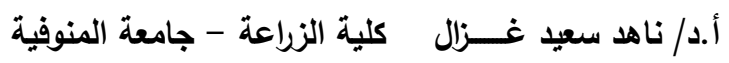


A. Fekry, et al., 


\section{English Summary Studies on promoter expression of toxins genes in Salmonella}

This work provides the evidence that considerable increase in Salmonella activity takes place within $24 \mathrm{~h}$ at ambient and above room temp up to $4 \cdot{ }^{\circ} \mathrm{C}$. The temperature range for the growth of Salmonella spp. is 5 to $40^{\circ} \mathrm{C}$, where the optimal temperature range lies in between 35 and $40^{\circ} \mathrm{C}$. Exposure to high temperature, Salmonella Typhimurium serovar was found to be more sensitive. We provided the evidence that concentration of Salmonella total RNA indicates its preparedness in the form of metabolic and cellular activities to cope with environmental stress while in contact with epithelial cells (IEC-6) led to an increase in the production of toxin. Relative expression of temperature of toxin gene and virulent genes of Salmonella reveals both in terms of activation and repression of target genes in diverse expression modes depending on the cellular activity. Salmonella Typhimurium seems to be more potent and showed increased ability to induce the expression of enterotoxin gene (stn) by the exposure of temperature elevation. 